\title{
PENDIDIKAN FUTURISTIK SEBAGAI UPAYA PENINGKATAN KUALITAS PESERTA DIDIK
}

\author{
Muzamil \\ Dosen Sekolah Tinggi Agama Islam (STAI) \\ Ma'had Aly Al-Hikam Malang \\ Jl. Cengger Ayam No. 25 Malang \\ Email : muzamilzaini099@gmail.com
}

\begin{abstract}
Abstrak
Setiap peserta didik merupakan sumberdaya manusia yang diidealisasikan menjadi sumber kekuatan strategis bangsa sekarang maupun masa mendatang. Konstruksi hidup berbangsa dan bernegara ditentukan oleh kualitas peserta didik yang terbentuk dengan baik dan benar melalui suatu proses pembelajaran. Dari proses pembelajaran ini akan bisa diharapkan atau dihasilkan pendidikan yang berorientasi futuristic, yakni pendidikan yang memberikan pola berfikir dan beraktifitas demi masa depannya. Proses pembelajaran berbasis multikultural merupakan salah satu model yang bisa digunakan oleh dunia pendidikan.
\end{abstract}

Kata kunci: pendidikan, futuristik, pembelajaran, proses, multikultural

\section{Abstract}

Each student is a human resource that is idealized as a source of national and present strategic strength. The construction of national and state life is determined by the quality of students formed properly and correctly through a learning process. From this learning process, it can be expected or produced futuristic oriented education, namely education that provides thinking patterns and activities for the future. The multicultural-based learning process is one model that can be used by the educational world. Keywords: education, futuristic, learning, process, multicultural

\section{PENDAHULUAN}

Dewasa ini ada kecenderungan yang memprihatinkan berkaitan dengan kondisi peserta didik yang tidak memahami keberagaman (heteroninitas atau pluralisme). Hal ini dapat terbaca dalam sikap dan perilakunya yang gampang menempatkan orang lain, sesama, atau siapapun yang berbeda dengan dirinya bukan sebagai subyek yang dihormati hakhaknya.

Kasus perkelahian atau tawuran antar peserta didik yang sering terjadi yang mengakibatkan meninggal dunia, luka serius, dan kerugian lainnya adalah salah satunya diakibatkan oleh ketidakpahaman atau adanya 
sikap yang tidak menghormati pluralitas baik dari segi budaya, pemikiran, ekonomi, moral, maupun agamanya. Mereka terjerumus dalam penyikapan kalau yang lainnya harus dikalahkan dan dibantai.

Menyikapi hal itu, pembelaan atau apologi yang sering dikemukakan kalangan penyelenggara pendidikan berkaitan dengan "kegagalan" tersebut adalah derasnya arus globalisasi informasi dan budaya, yang membuat dunia pendidikan menjadi "gagap" dalam melawan dan mengalahkan perubahan budaya (kultur). Mereka sering berdalih bahwa teknologi informasi global dan globalisasi serta revolusi budaya telah mengakibatkn ketahanan moralspiritual anak-anak didik menjadi rentan.

Memang di satu sisi tidak bisa dipungkiri, kalau pengaruh globalisasi kultural telah mengakibatkan anak-anak didik rentan terjerumus dalam mengadopsi perubahan gaya hidup. Fakta menunjukkan, bahwa tidak sedikit kita jumpai anak-anak kita yang berada di tepi jurang kehancuran akibat terperangkap dalam hegemoni gaya hidup hedonisme dan permisifisme. Mulai dari gaya berpacaran serba bebas, keterlibatan dalam aksi kekerasan hingga penyalahgunaan zat-zat adiktif, tawiran, atau polapola berbudaya menyimpang telah membuat dirinya dijuluki sebagai peserta didik yang berada dalam ranah "salah asuhan".

Meski begitu, dalih yang menyebut kalau globalisasi informasi dan revolusi kultural yang paling bersalah dalam dunia pendidikan, jelas tidak rasional diajukan oleh penyelenggara pendidikan, karena selain kecenderungan ke depan akan semakin gencar dan represip perubahan di sektor informasi dan kultur, elite strategis pendidikan ini sudah mendapatkan amanat menstransformasi dan membudayakan doktrin adiluhung seperti kejujuran, kebenaran, keadilan, dan keadaban.

\section{METODE PENELITIAN}

Tulisn ini merupakan deskripsi dari riset secara kualitatif dengan menggunakan bahan primer, sekunder, dan tersier. Teknik pengumpulan bahan menggunakan dokementasi dari sejumlah literatur atau keputusan, yang dipilah-pilah yang relevan dengan obyek yang dibahas. Analisinya menggunakan analisis deskriptif kualitatif. Dalam analisis ini ada deskipsi yang bersifat penajaman dan komparatif.

\section{PEMBAHASAN}

Pendidikan dalam arti teoritik filosofis adalah pemikiran manusia terhadap masalah-masalah kependidikan untuk memecahkan dan menyusun teori-teori baru dengan mendasarkan kepada pemikiran normatif, spekulatif, rasional empirik, rasional filosofik maupun historik filosofik. Sedangkan pendidikan dalam arti praktek, adalah suatu proses pemindahan atau 
transformasi pengetahuan ataupun pengembangan potensi-potensi yang dimiliki subjek didik untuk mencapai perkembangan secara optimal, serta membudayakan manusia melalui transformasi nilai-nilai yang utama. ${ }^{1}$

lebih kurang 600 tahun sebelum Masehi, telah dinyatakan orang Yunani, bahwa pendidikan ialah usaha manusia untuk menjadi manusia. Ada dua kata yang penting dalam kalimat itu, pertama "membantu" dan kedua "manusia". Manusia perlu dibantu agar menjadi manusia. Seseorang dapat dikatakan telah menjadi manusia bila telah memiliki nilai (sifat) kemanusiaan. Hal ini menunjukkan bahwa tidaklah mudah menjadi manusia. Karena itulah sejak dahulu manusia sering gagal menjadikan dirinya sebagai manusia. Jadi, tujuan mendidik ialah memanusiakan manusia. Agar tujuan itu dapat dicapai dan agar progam dapat disusun maka cici-ciri manusia yang telah menjadi manusia itu haruslah jelas. ${ }^{2}$

Dalam pasal 3 Undang-undang Nomor 20 Tahun 2003 tentang Sistem Pendidikan Nasional, bahwa pendidikan nasional berfungsi mengembangkan kemampuan dan membentuk watak serta peradaban bangsa yang bermartabat dalam rangka mencerdaskan kehidupan bangsa, bertujuan untuk berkembangnya potensi peserta didik agar menjadi manusia yang beriman dan bertakwa kepada Tuhan Yang Maha Esa, berakhlak mulia, sehat, berilmu, cakap, kreatif, mandiri, dan menjadi warga negara yang demokratis serta bertanggung jawab.

landasan yuridis itu menunjukkan, bahwa dunia pendidikan bukan sekedar menghasilkan manusia yang trampil atau pintar. Sosok demikian belum cukup atau baru separuh jalan untuk diandalkan membangun dan mencerahkan masyarakat dan bangsa. Dari segi sisi kemajuan Iptek, barangkali syarat pintar dan trampil menjadi syarat privilitas yang menentukan, akan tetapi syarat fundamental yang menentukan keberlanjutan dan pencerahan peradaban atau bangunan kuktur sangat ditentukan oleh bagaimana penyelenggaraan pendidikan bisa menghasilkan sosok pengabdi kebenaran atau manusia berkarakter pejuang.

Pendidikan dalam istilah Al-Qur'an-nya disebut "tarbiyah", yang mengandung arti "penumbuhan" atau "peningkatan jasmani anak".pertamatama ialah penumbuhan dan peningkatan segi jasmani anak, dengan terutama si ibu tanpa pamrih dan atas rasa cinta kasih sayang yang semurnimurninya mencurahkan diri dan perhatiannya kepada pertumbuhan anaknya. Hubungan emosional yang amat peka dan penuh kemesraan si ibu menjadi taruhan "survival"si anak memasuki dunia kehidupan. Bahkan hubungan itu

\footnotetext{
${ }^{1}$ Chabib Thoha, Kapita Selekta Pendidikan Islam, (Yogyakarta: Pustaka Pelajar, 1996), 98-99

${ }^{2}$ Ahmad Tafsir, Filsafat Pendidikan Islam, (Bandung: Remaja Rosdakarya, 2006), 33.
} 
sudah terbentuk saat berada dalam kandungan.sedemikian pekanya unsur cinta kasih itu, sehingga tempat janin dalam bahasa arab disebut rahm (rahim secara etimologis berarti kasih sayang) ${ }^{3}$

Kiai Sahal Mahfud dalam Nuansa Fiqih Sosial juga menyebut, bahwa pendidikan sejatinya merupakan usaha sadar yang membentuk watak dan perilaku secara sistematis, terencana dan terarah, yang berarti substansi privilitas at-tarbiyah ini tak hanya terletak pada transformasi knowledge, tetapi juga berelasi dengan masalah character building. ${ }^{4}$

Untuk menghasilkan sosok berkarakter pengabdi pada kebenaran tidaklah mudah dilakukan oleh dunia pendidikan, bahkan lembaga pesantren yang semula dikenal sebagai institusi sakral yang digaransi bisa menghasilkan kiai kharismatik, sekarang pun seringkali digugat, karena tidak sedikit peserta didik yang berasal atau dibesarkan di pesantren, yang gagal menjaga nilai-nilai kesantriannya atau tidak menunjukkan diri sebagai pejuang (pengabdi) kebenaran ketika sudah keluar dari pesantren.

Kebermaknaan hidup seseorang ditentukan oleh kemampuannya dalam menjawab tantangan yang dihadapinya. Ia layak disebut sukses menjalani tugasnya sebagai khalifah di muka bumi, bilamana tantangan yang dihadapinya tidak mengorbankannya menjadi sosok manusia yang menyerah kalah dalam kegagalan. ${ }^{5}$

Salah satu problem serius atau masalah mutakhir yang dihadapi oleh masyarakat atau negara ini adalah masalah sumber daya manusia. Problem ini bukan hanya menimpa dunia politik, budaya, dan agama, tetapi juga pendidikan. Banyak masalah di dunia pendidikan yang berhubungan dengan masalah kondisi sumber daya manusia. Ketika masyarakat di negara-negara maju memperbincangkan masalah peningkatan peradabannya, masyarakat atau negara ini masih sibuk mengurus upaya membenahi sektor sumber daya manusianya. ${ }^{6}$

Realitas dalam kehidupan kemasyarakatan dan kebangsaan ditentukan oleh salah satu potret berupa hubungan antara pendidikan dan sumber daya manusia. Ketika kondisi sumber daya manusia berkualitas unggul seperti mampu menunjukkan prestasi-prestasi besar, maka yang akan mendapatkan penilaian awal adalah peran dunia pendidikan Islam yang ikut menentukannya. 1997), 114.

${ }^{3}$ Nurcholish Madjid, Masyarakat religius, (Jakarta: Amanah Putra Nusantara,

4 Ahmad Fadeli, dkk Pendidikan Islam sebagai pembentuk Karakter Peserta Didik, LKPPI, 15 Agustus, 2015, Malang. 2.

${ }^{5}$ Mahfud, Pribadi yang Pintar dan Benar, materi Kultum bagi Kaum terdidik, (Surabaya: Prima Mustika, 2006), 9.

${ }^{6}$ Ibid. 13. 
Muhammad Tholchah Hasan menyebut, bahwa memahami masalah pembangunan atau pengembangan sumber daya manusia, termasuk peserta didik perlu dikemukakan hal-hal mendasar sebagai berikut:

Pertama: pengembangan sumber daya manusia (pada hakikatnya adalah upaya untuk mewujudkan dan mengembangkan seluruh daya manusia secara terpadu, sehingga diperoleh kompetensi-kompetensi tertentu. Karena sifat peningkatan dalam kualitas ini, maka pengembangan sumber daya manusia menganut paradigma nilai tambah baik dalam konteks teknologi, ekonomi, maupun sumber daya manusia adalah suatu mentefak (yaitu perubahan pada tingkat pikiran, gagasan, teori, nilai dan paradigma). Dengan demikian nilai tambah tersebut memerlukan elaborasi pada tingkat spesifik (yaitu budaya perubahan satu lingkungan yang lebih besar sebagai kepompong bu,daya manusia, atau perubahan ekosistem manusia, seperti pranata sosial dan sebagainya), dengan artefak (yaitu perubahan fisik yang terjadi sebagai hasil intervensi manusia terhadap lingkungannya dengan ilmu dan teknologi).

Kedua, sesuai dengan sejarah perkembangannya, yang awalnya berpijak pada nilai tambah. Nilai tambah sebagai paradigma pembangunan setidaknya mempunyai dimensi makna lain, yaitu makna non ekonomis pada dimensi kemanusiaan, nilai ekonomis menjadikan manusia lebih produktif, dan nilainya menjadi lebih unggul secara ekonomuis. Sedangkan nilai tambah insani (kemanusiaan) menjadikan manusia lebih tinggi harkat dan martabat kemanusiaannya, yaitu manusia yang lebih berbudaya, berakhlak, beriman dan bertaqwa, berseni dan sebagainya.

Ketiga, secara empiris, pengembangan sumber daya manusia meliputi empat aspek yang saling terkait yaitu: 1) Peningkatan kesejahteraan kualitas hidup, 2) Pengembangan tenaga dan kesempatan kerja, 3) Pengembangan potensi insani, (akal, qolbu, serta fisik), 4) Pengembangan kemampuan menguasai, memanfaatkan dan mengembangkan teknologi.

Keempat, pada tingkat makro perkembangan sumber daya manusia akan terjadi sebagai hasil interaksi antara pertumbuhan/perkembangan ekonomi, perkembangan sosial budaya (termasuk nilai-nilai spiritual) dan perkembangan serta penerapan teknologi. Ketiga proses tersebut dapat berpengaruh secara sinergis terhadap perkembangan sumber daya manusia. Berbeda dengan interdepedensi diatas perkembangan kualitas sumber daya manusia, suatu bangsa dapat makin mempercepat pertumbuhan ekonomi, namun sebaliknya, pertumbuhan ekonomi tidak dengan sendirinya menjamin terjadinya perkembangan kualitas sumber daya manusia. Perkembangan dan pertumbuhan ekonomi yang berorientasi pada "nilai 
tambah" yang memungkinkan pengaruhnya pada perkembangan kualitas sumber daya manusia. ${ }^{7}$

Pemikiran terhadap masalah pendidikan sumberdaya manusia tersebut sejalan dengan pemikiran pemikir muslim kenamaan Al-Ghazali. Al-Ghazali merupakan salah satu ulama yang serius memikirkan masalahmasalah pendidikan. Al-Ghazali merupakan figur yang dapat dijadikan acuan keteladanan dalam dunia pendidikan, karena ia punya perhatian khusus terhadap masalah pengembangan sumber daya manusia yang berpangkal pada masalah pendidikan moral kerakyatan. Artinya, dalam menjalankan tugas kekhalifahan di muka bumi, manusia harus terdidik secara moral supaya peran yang dilakukan benar-benar sejalan dengan ajaran Ilahi, dan bukan mengikuti segala kemauan yang mengarah pada perusakan dan penghancuran.

Bagi masyarakat pembelajar, pemikiran kependidikan Al-Ghazali tersebut dapat dijadikan sebagai sumber referensi pemikiran untuk membangun dunia pendidikan Islam di Indonesia, khususnya pendidikan etikanya, yang mengandung substansi pencegahan diri dari kemungkinan melakukan tindakan yang merugikan orang lain dan makhluk Tuhan lainnya.

Dalam pemikiran ahli fikih kenamaan Sahal Mahfud, pendidikan pada dasarnya adalah usaha sadar yang membentuk watak dan perilaku secara sistematis, terencana, dan terarah. ${ }^{8}$ Usaha seperti menunjukkan, bahwa dunia pendidikan merupakan tempatnya aktifitas yang mengerahkan berbagai kemampuan terbaik untuk menyukseskan cita-cita luhur berkaitan dengan pembentukan sumber daya manusia Indonesia.

Brubacher mengatakan: "Education is the organized development and equipment of all the powers of a human being, moral, intellectual and physical, by and for their individual and social uses, directed toward the union of these activities with their creator as their final and" pengertian ini bisa diterjemahkan berikut: pendidikan merupakan perkembangan yang terorganisir dan kelengkapan dari semua potensi manusia, moral, intelektual maupun jasmani, oleh dan untuk kepribadian andividunya dan kegunaan masyarakatnya, yang diarahkan untuk menghimpun semua aktivitas tersebut bagi tujuan hidupnya yang akhir".

Rumasan tersebut menunjukkan, bahwa pendidikan merupakan suatu aktifitas yang menempatkan manusia sebagai subyeknya. Aktifitas ini

${ }^{7}$ Muhammad Tholhah Hasan, Diskursus islam kontemporer, (Jakarta: Listafariska Putra, 2000), 55-57.

${ }^{8}$ Sahal Mahfudh, Nuansa fiqih sosial, (Yogyakarta: LKIS, 1994), 257.

${ }^{9}$ Muhammad Tholhah Hasan, Islam dalam Perspektif Sosial Budaya, (Jakarta: Galasa Nusantara, 1987), 16-17. 
berkaitan dengan transformasi ilmu pengetahuan yang diarahkan pada pembentukan kepribadian manusia secara fisik maupun non-fisik. Kepribadian manusia menjadi fokus utama proses pendidikan atau pembelajaran. Hal ini sesuai dengan salah satu unsur pendidikan yang menyebutkan, bahwa di dalam pendidikan terkandung usaha secara terarah untuk mengembangkan kepribadian anak (peserta didik).

Pada tingkat idividual, pendidikan memberikan kreatifitas, kesadaran estetis serta bersosialisasi dengan norma-norma, nilai-nilai dan keyakinan sosial yang baik. Orang yang berpendidikan diharapkan lebih mampu menghargai atau menghormati perbedaan dan pluralitas budaya sehingga memiliki sikap yang lebih terbuka terhadap keanekaragaman budaya. Sedangkan fungsi kependidikan merujuk pada sumbangan kependidikan terhadap perkembangan dan pemeliharaan pendidikan diharapkan bagi manusia memiliki kesadaran untuk belajar sepanjang hayat, selalu merasa ketinggalan informasi, ilmu pengetahuan serta teknologi sehingga terus terdorong untuk maju dan terus belajar. ${ }^{10}$

Al-Ghazali menggunakan empat istilah dalam membahas tentang esensi manusia yaitu: 1) hati (qalb) ialah, yang halus, ketuhanan yang bersifat kerohanian, ia dengan hati yang bertubuh ada hubungannya, 2) ruh adalah yang halus, yang mengetahui, dan yang merasa dari manusia, 3) jiwa (nafs) yaitu yang halus yang telah kami sebutkan yakni hakekat manusia; diri dan zatnya, 4) akal (aql) kadang ditujukan dan dimaksudkan yang memperoleh pengetahuan, dan itu adalah hati yakni yang halus, kadang dimaksudkan sifat orang yang berilmu, dan kadang dituijukan dan dimaksudkan tempat pengetahuan yakni yang mengetahui

Penggunaan keempat istilah diatas menunjukkan bahwa kajian AlGhazali terhadap esensi manusia sangat mendalam menyertai sepanjang perkembangan pemikirannya. Saat berbicara tentang filsafat, ia lebih sering menggunakan kata nafs dan akal, sedangkan ruh dan qalb lebih banyak dijumpai dalam kitab-kitabnya ditulis setelah menekuni tasawuf, akan tetapi hal itu tidak mengubah pandangannya tentang esensi manusia. ${ }^{11}$

Berkaitan dengan fokus pada manusianya ini, perlu kiranya dipahami mengenai tujuan pendidikan. Tujuan penddikan ini akan sama dengan gambaran manusia terbaik menurut orang tertentu. Mungkin saja seseorang tidak mampu melukiskan dengan kata-kata tentang bagaimana manusia yang baik yang ia maksud. Sekalipun demikian tetap saja ia menginginkan tujuan pendidikan itu haruslah manusia terbaik. Tujuan pendidikan sama dengan tujuan manusia. Manusia menginginkan semua

\footnotetext{
${ }^{10}$ Muhammad Tholchah Hasan, Op.Cit. 4-5

${ }^{11}$ Abidin Ibnu Rusn, Pemikiran Al- ${ }^{\text {Ghazali }}$ tentang pendidikan, (Yogyakarta: Pustaka Pelajar, 1998), 30-31
} 
manusia, termasuk anak keturunannya, menjadi manusia yang baik. Sampai di sini tidaklah ada perbedaan akan muncul tatkala merumuskan ciri-ciri manusia yang baik itu. ${ }^{12}$ Kata Ahmad Syafii Maarif, ${ }^{13}$ manusia yang baik merupakan sosok manusia yang tidak menghabiskan masa hidup yang ringkas ini dengan sia-sia.

Manusia hidup di alam, dan menjadikan alam sekitar kehidupannya. Bahkan manusia menjadi bagian dari alam sekitarnya. Tetapi manusia bukanlah bagian dari alamnya sebagaimana bagian-bagian alam lainnya. Manusia merupakan bagian alam aktif. Manusia mendapatkan dan mengambil kebutuhan hidupnya dari alam sekitarnya dan mengolah sedemikian rupa sehingga sesuai dan memadai deengan kebutuhannya. Bahkan manusia memiliki kemampuan untuk mengubah dan menyesuaikan alam sekitarnya menurut dan sesuai dengan kebutuhan hidupnya, manusia berbudaya dan membudayakan alam lingkungannya, untuk mendapatkan kehidupan yang baik, enak dan nyaman. ${ }^{14}$.

Dalam pemahaman BS Mardiatmadja ${ }^{15}$, pendidikan merupakan suatu usaha bersama dalam proses terpadu (terorganisir) untuk membantu manusia mengembangkan diri dan menyiapkan diri guna mengambil tempat semestinya dalam pengembangan masyarakat dan dunianya di hadapan Sang Pencipta. Dengan proses itu, seorang manusia dibantu untuk menjadi sadar akan kenyataan-kenyataan dalam hidupnya, bagaimana dimengerti, dimanfaatkan, dihargai, dicintai, apa kewajiban-kewajiban dan tugastugasnya agar dapat sampai kepada alam, sesama, dan Tuhan, sebagai tujuan hidupnya.

Mengapa manusia perlu dididik? Atau mengapa manusia perlu dibimbing, dibina, diarahkan, atau diberi bekal ilmu pengetahuan yang memadai? adalah pertanyaan-pertanyaan yang mengarah pada tujuan manusia perlu atau harus dididik. Manusia dididik (mengacu pada tujuan pendidikan nasional) misalnya untuk memiliki kekuatan moral spiritual, di samping kemampuan lainnya. Dengan memiliki kekuatan ini, tentulah diharapkan sosok ini tidak menunjukkan sikap dan perilaku yang bercorak melanggar hak-hak orang lain, atau di dalam dirinya ada kekuatan pengendalian, sehingga tidak sampai menjadi pelaku sosial yang merugikan sesama dan makhluk lainnya di muka bumi.

${ }^{12} \mathrm{Ibid}, 76$

${ }^{13}$ Ahmad Syafii Maarif, Membumikan Islam, (Yogyakarta: Pustaka Pelajar, 1995), 11.

${ }^{14}$ Zuhairi, dkk, Filsafat Pendidikan Islam, (Bandung: Bumi Aksara, 2004), 33.

${ }^{15}$ BS. Mardiatmadja, Tantangan Dunia Pendidikan, (Yogyakarta: Kanisius, 1986), 
Hal itu sebagaimana tujuan pendidikan nasional, bahwa tujuan pendidikan nasional sebagaimana telah digariskan di dalam pasal 3 Undangundang Nomor 20 Tahun 2003 tentang Sistem Pendidikan Nasional, bahwa pendidikan nasional berfungsi mengembangkan kemampuan dan membentuk watak serta peradaban bangsa, bertujuan untuk berkembangnya potensi peserta didik agar menjadi manusia yang beriman dan bertakwa kepada Tuhan Yang Maha Esa, berakhlak mulia, sehat, berilmu, cakap, kreatif, mandiri, dan menjadi warga negara yang demokratis serta bertanggungjawab.

Sistem pendidikan nasional tersebut merupakan pijakan umum yang digunakan oleh setiap institusi atau lembaga-lembaga pendidikan, termasuk lembaga pendidikan Islam. Dalam sistem pendidikan ini harus terjadi kesatuan gerak antar komponen yang bisa mengantarkan atau menjembatani terwujudnya tujuan pendidikan nasional. Peserta didik menempati posisi strategis karena ia menjadi subjek yang dididik dan dikembangkan, sehingga diharapkan menjadi manusia yang berguna. Peserta didik bukan hanya dididik untuk menjadi manusia yang cakap, pintar, dan berilmu, tetapi juga dibentuk pribadinya supaya menjadi sosok yang beriman. Sosok beriman merupakan unsur utama yang diharapkan bisa terwujud dalam penyelenggaran pendidikan Islam.

Dalam sistem pendidikan, setiap unsur adalah pilar pendidikan. Pendidikan tidak hanya tergantung dan ditentukan oleh peran dosen, guru atau kiai, tetapi juga ditentukan oleh keterlibatan aktif peserta didik (siswa/mahasiswa/santri) dalam proses pendidikannya. Kalau gurunya aktif, sementara peserta didik atau mahasiswanya tidak aktif, maka sistem pendidikan tidak akan bisa berjalan dengan baik. Jika sistemnya tidak bisa berjalan dengan baik, maka tujuan pendidikan bisa gagal atau terhambat.

Peran masing-masing unsur dalam dunia pendidikan akan menentukan keberhasilan tidaknya suatu proses pembelajaran. Dosen atau guru saja (pendidik) saja yang berperan, sementara mahasiswa tidak menunjukkan usaha-usaha maksimalnya, maka proses pembelajaran tidak akan berhasil. Ketika proses demikian gagal, maka tujuan pendidikan pun tidak akan sukses. Kegagalan pendidikan ini tentulah berdampak secara makro bagi kualitas hidup masyarakat dan bangsa, karena dari pendidikan inilah berbagai bidang strategis dipengaruhinya.

\section{Proses Pendidikan Futuristik}

Peran pendidik dan peserta didik dalam proses pembelajaran multikultural sudah jelas, yakni keduanya harus terliat aktif sebagai subyek. Pendidik menyampaikan substansi smultikultural, sementara pserta didik menjadi subyek yang menerima transformasinya. 
Pendidik dan peserta didik perlu mmahami lebih dulu tentang esensi multikulturalisme. Banyak ahli berbeda dalam memahami multikulturalisme. Ada yang cukup menyebut, bahwa multikulturalisme identik dengan keragaman kultural atau kebudayaan. Menurut Parsudi Suparlan (2002) akar kata dari multikulturalisme adalah kebudayaan, yaitu kebudayaan yang dilihat dari fungsinya sebagai pedoman bagi kehidupan manusia. Dalam konteks pembangunan bangsa, istilah multikultural ini telah membentuk suatu ideologi yang disebut multikulturalisme.

Menurut Azyumardi Azra (2007) "multikulturalisme" pada dasarnya adalah pandangan dunia yang kemudian dapat diterjemahkan dalam berbagai kebijakan kebudayaan yang menekankan penerimaan terhadap realitas keagamaan, pluralitas, dan multikultural yang terdapat dalam kehidupan masyarakat. Multikulturalisme dapat juga dipahami sebagai pandangan dunia yang kemudian diwujudkan dalam kesadaran politik.

M. Atho' Muzhar menyebut, bahwa multikulturalisme mencakup gagasan, cara pandang, kebijakan, penyikapan dan tindakan, oleh masyarakat suatu negara, yang majemuk dari segi etnis, budaya, agama dan sebagainya, namun mempunyai cita-cita untuk mengembangkan semangat kebangsaan yang sama dan mempunyai kebanggan untuk mempertahankan kemajemukan tersebut.

Berdasarkan pemikiran tersebut, dapat dipahami bahwa multikulturalisme pada dasarnya merupakan konsep dimana sebuah komunitas dalam konteks kebangsaan dapat mengakui keberagaman, perbedaan, dan kemajemukan budaya, ras, agama, dan bahasa. Multikulturalisme menjadi gambaran dari keragaman yang terjadi dan berkembang di tengah masyarakat atau suatu bangsa di muka bumi ini.

Multikulturalisme juga sebuah konsep yang memberikan pemahaman, bahwa sebuah bangsa yang plural adalah bangsa terdiri dari beberapa etnis, budaya, agama, tradisi dan bahasa yang bermacam-macam, yang dapat hidup berdampingan dan saling menghormati dalam suasana damai dan rukun (co-existence).

Multikulturalisme merupakan realitas kehidupan masyarakat dan bangsa, meski tidak setiap subyek masyarakat atau bangsa ini mau mengakui dan menerimanya. Selain itu, multikulturalisme ini juga mengalami dinamika sesuai dengan tingkat aktifitas, upaya atau prestasi yang ditunjukkan masyarakat atau bangsa itu.

Suparlan mengutip Fay (1996), Jary dan Jary (1991), Watson (2000) dan Reed (ed. 1997) menyebutkan bahwa multikulturalisme ini akan menjadi acuan atau referensi utama bagi terwujudnya masyarakat multikultural, karena multikulturalisme sebagai sebuah ideologi akan mengakui dan mengagungkan perbedaan dalam kesederajatan baik secara 
individual maupun secara kultural dan kelompok. Dalam kelompok sosial, sekecil apapun kelompok ini, jika direfleksi dan dibaca dengan nalar yang obyektif, maka multikultural akan diakuinya sebagai realitas, termasuk kehadiran model-modelnya.

Beberapa ahli itu sudah menempatkan multilturalisme sebagai model. Artinya dalam model multikulturalisme ini, sebuah masyarakat, termasuk juga masyarakat Indonesia atau masyarakat manapun di muka bumi, khususnya yang kondisinya seperti Indonesia, mempunyai sebuah kultur yang berlaku general dalam masyarakat yang coraknya seperti suatu mosaik.

Di dalam mosaik itu tercakup semua kebudayaan dari masyarakatmasyarakat yang lebih kecil yang membentuk terwujudnya masyarakat yang lebih besar, yang mempunyai kultur seperti sebuah mosaik, multikulturalisme diperlukan dalam bentuk konstruksi kehidupan masyarakat dan bangsa, sehingga terwujud keharmonisan dalam keragaman kultural atau berbudaya dalam realitas keragaman.

McCormick (1983) menyebutkan empat model multikulturalisme dalam konteks pembentukan suatu bangsa, yaitu :

Pertama; model melting pot, dalam pengertian peleburan etnisitas dan budaya menjadi sebuah bangsa baru, sehingga ciriciri etnisitas dan budaya lama yang membentuk kesatuan bangsa itu menjadi hilang.

Kedua; model assimilation, yaitu suatu pandangan yang membenarkan iliminasi perbedaan-perbedaan yang ada dan membaur dengan budaya kelompok yang dominan. Biasanya warna budaya kelompok dominan tersebut yang masih mudah dikenali meskipun sudah berkurang, sebaliknya budaya kelompok lemah akan menjadi kabur dan hilang.

Ketiga; model salad bowi, yang memandang keharusan setiap individu atau kelompok dalam suatu masyarakat harus menghormati keragaman kultural (cultural diversity) yang berasal dari etnis, budaya, agama, bahasa, dan wilayah dimana individu dan kelompok berasal. Dan pada saat yang sama mendukung kesepakatan yang telah di setujui bersama untuk bersatu dan saling menghormati dalam satu wadah dan hidup berdampingan secara damai. Bangsa Indonesia mengikuti model ketiga ini dengan semboyan "Bhineka Tunggal Ika".

Keempat; model open nation, suatu pandangan masyarakat terbuka, masyarakat dengan segala keberagamannya dibebaskan mengambil cara yang dikehendaki dalam membentuk suatu bangsa.

Inti pendidikan multikulturalisme tersebut terletak pada proses transformasi ilmu pengetahuan tentang peran manusia dalam keberagaman 
dalam lingkupbudaya maupun lainnya, dimana manusia menjadi subyek yang menentukan.

Persoalan sosok manusia yang menjadi sumberdaya strategis dalam dunia pendidikan telah banyak disinggung oleh kalangan ahli, di samping memang tema pokok Al-Qur'an sebenarnya adalah tentang manusia dan masalah yang dihadapinya dalam kehidupan. Bila ditengok secara fisik, manusia tidak banyak berbeda dengan makhluk yang lain. Tapi dari segi ruhani, perbedaan itu sangat kentara ${ }^{16}$ Dalam ranah ini jelas, bahwa setiap diri manusia harus siap menghadapi kondisi multikulturalisme.

Disebutkan pula dalam Imad al-Din Khalil, bahwa manusia dengan posisinya sebagai khalifah Allah di muka bumi diberikan kekuasaan (quddira lahu) untuk menciptakan peristiwa-peristiwa sejarahnya dengan kemauan dan ikhtiarnya, baik untuk tujuan negatif maupun positip. ${ }^{17}$ Tujuan demikian menjadi bukt keragaman, artinyasetiap manusia mempunyai pola dan tujuan yang bersifat pluralistik.

Manusia diberi predikat Khalifah Allah di bumi ini membawa arti bahwa manusia diberi kewenangan untuk mengelola bumi dan segala isinya. Mengelola dunia hanya akan dapat dilakukan oleh orang yang memiliki kemampuan dan ilmu pengetahuan. Karenanya sangat jelas, wahyu pertama yang turun adalah surat Al-Alaq ayat 1-5, yaitu perintah untuk membaca. Sejarah juga mencatat, ketika Perang Badar, banyak dari kaum Quraisy yang kalah dalam peperangan akhirnya menjadi tawanan. Rasulullah SAW akan membebaskan tawanan itu, jika mereka mau mengajarkan membaca dan menulis kepada sepuluh umat Islam. Catatan sejarah itu menunjukkan begitu besarnya perhatian umat Islam terhadap upaya memerangi kebodohan dan keterbelakangan. Hal ini dimaksudkan agar umat Islam tidak menjadi kaum yang marginal, tidak tergilas derasnya kemajuan ilmu pengetahuan dan teknologi. ${ }^{18}$

Allah SWT dan RasulNya telah memberi petunjuk berharga bahwa perubahan seorang manusia, masyarakat, bangsa, ataupun umat manusia secara umum sangat ditentukan bagaimana mereka berusaha untuk melakukan perubahan tersebut. Perubahan merupakan indikasi hasil usaha atau aktifitas yang dilakukan oleh manusia dalam menjalani kehidupan secara individual maupun bersama-sama dengan orang lain.

Perubahan yang mengandalkan kekuatan ilmu pengetahuan itu, dengan pendidik atau sumberdaya manusia dari golongan, etnis, dan berbudaya apapun itu menunjukkan, bahwa proses pembelajaran multikultural sudah

\footnotetext{
${ }^{16}$ Ahmad Syafi'i Maarif, Op.Cit, 9.

${ }^{17}$ Ibid.

${ }^{18}$ Hamdani, Musuh Manusia, Republika, 7 Juni 2006, dalam Ahmad Fadeli, dkk,
} Op.Cit, 11. 
diberikan contoh (teladan) oleh Nabi Muhammad SAW, sehingga suatu kekeliruan kalau di zaman sekarang ini masih ada orang yang mempersoalkan belajar pada seseorang pendidik lintas agama dan budaya, justru yang harus dipertimbangkan adalah transformsi ilmu pengetahuan secara futuristik melalui pembelajaran multikultural.

"Bagi manusia ada malaikat-malaikat yang selalu mengikutinya bergiliran, di muka dan di belakangnya, mereka menjaganya atas perintah Allah. Sesungguhnya Allah tidak merobah Keadaan sesuatu kaum sehingga mereka merobah keadaan yang ada pada diri mereka sendiri. dan apabila Allah menghendaki keburukan terhadap sesuatu kaum, Maka tak ada yang dapat menolaknya; dan sekali-kali tak ada pelindung bagi mereka selain Dia (QS Ar-Ra'ad (13): 11).

Sejarah pun telah membuktikan. Sebuah bangsa yang gigih dalam berjuang dan mengoptimalkan segala kemampuan dan sumber daya yang dimiliki, akan menjadi bangsa yang besar dan maju. Sebaliknya, bangsa yang hanya mengandalkan pinjaman dan belas kasihan dari lembagalembaga 'rentenir', maka bangsa tersebut tak akan pernah maju. Karena, bangsa seperti ini dengan mudah akan selalu diatur oleh lembaga donor tersebut. Bagi umat Islam, telah ada contoh nyata dari Rasulullah SAW yang terlahir dalam keadaan yatim. Beliau berusaha dan bekerja secara optimal hingga berhasil dan sukses menjadi pedagang dalam usia yang relatif muda. Beliau adalah public figure yang mengajarkan manusia supaya tidak kenal henti dalam melakukan berbagai bentuk perubahan dalam hidupnya. ${ }^{19}$

Wahyu Rasulullah sendiri merupakan uswah pertama dalam menuntut ilmu. Wahyu pertama yang beliau terima adalah perintah untuk menjadi orang berilmu melalui membaca (QS Al-Alaq (96): 1-5). Alquran dibaca supaya hidup teratur, sejarah dibaca supaya tahu peninggalan para leluhur, dan alam dibaca supaya lahir karya-karya yang luhur. Melalui bacaan ilmu pengetahuan diperoleh dan seseorang menjadi bijak dalam tutur kata dan perbuatan.

Menuntut ilmu juga tidak dibatasi oleh tempat. Dalam sebuah hadis riwayat Ibnu Uda, Rasulullah memerintahkan untuk menuntut ilmu sampai ke negeri Cina. Ini merupakan indikasi nyata bahwa Islam sangat menghargai ilmu pengetahuan. Ketika Rasulullah menganjurkan untuk belajar sampai ke negeri Cina tentu bukan harus belajar tafsir di sana, sebab bukan tempatnya. Begitu juga di Cina bukan tempat untuk belajar shalat ataupun menunaikan zakat. Cina pada zaman Nabi Muhammad SAW, 14

${ }^{19}$ Mulyana, Generasi Mandiri, Republika, 12 September 2006, dalam Mahfud, Op.Cit, 22. 
abad silam, adalah negara yang sudah maju dalam ilmu pengetahuan, teknologi, industri, dan perdagangan. Sehingga, Rasulullah menyuruh umatnya untuk belajar teknologi, perdagangan, dan industri sekalipun kepada orang yang berbeda keyakinan. Begitu istimewanya orang yang menuntut ilmu sampai diperbolehkan oleh Rasulullah untuk iri kepada mereka. Tentu saja iri tatkala ilmunya bermanfaat bagi orang lain. Rasulullah bersabda, "tidak boleh hasud (iri) kepada orang lain kecuali kepada orang yang diberi kekayaan oleh Allah, kemudian ia menggunakannya untuk membela kebenaran dan kepada orang yang diberi ilmu tatkala ilmunya diamalkan dan diajarkan kepada orang lain." (HR Bukhari Muslim). ${ }^{20}$ Hal ini menunjukkan derajat orang-orang yang menyibukkan diri dalam belajar, mengajar, mempelajari, atau mengkaji masalah keilmuan

Kedudukan orang yang mencari ilmu ini memang sangat luhur sampai Allah menjanjikan posisi yang amat tinggi bagi mereka. Dalam Firman Allah SWT berikut: "Hai orang-orang beriman apabila kamu dikatakan kepadamu: "berlapang-lapanglah dalam majlis", Maka lapangkanlah niscaya Allah akan memberi kelapangan untukmu. dan apabila dikatakan: "Berdirilah kamu", Maka berdirilah, niscaya Allah akan meninggikan orang-orang yang beriman di antaramu dan orang-orang yang diberi ilmu pengetahuan beberapa derajat. dan Allah Maha mengetahui apa yang kamu kerjakan (QS Al-Mujadilah (58): 11).

Di dunia ini, banyak orang berburu gelar, meski kadang-kadang tidak tahu persis mana gelar terbaik yang seharusnya direbut. Banyak gelar bisa diraih, namun gelar yang sesungguhnya belum tentu bisa didapatkan. Ada label yang mudah dipasang pada nama seseorang, di depan maupun di belakang, tetapi ada label yang tidak perlu dipasang atau dikenal masyarakat, sementara label ini justru berharga sekali dalam perjalanan kehidupan seseorang. ${ }^{21}$

Tuhan sudah mengingatkan, bahwa di dunia ini ada kesenangan yang menipu, ada kesenangan yang menyesatkan, ada kesenangan yang menggoda, yang bilamana tidak hati-hati, akan banyak manusia di dunia yang jadi korban. Dalam hal gelar pun demikian, banyak orang yang sekedar bergelar, namun miskin kemampuan atau tidak memiliki kapabilitas yang sesuai dengan gelar yang diperolehnya. Ada diantara kita yang sekedar punya gelar, punya kepangkatan, atau status, tanpa mempertimbangkan kalau apa yang melekat dalam dirinya ini mengandung pertanggungjawaban moral. Gelar tinggi mencerminkan ketinggian ilmu.

${ }^{20}$ Uwes fathoni, Menuntut Ilmu, Republika, 15 Pebruari 2008, dalam Ahmad Fadeli, dkk, Op.Cit, 8.

${ }^{21}$ Ibid. 
Kepangkatan yang melekat mencerminkan amanat yang harus tegak kokoh. $^{22}$

"Manusia yang paling baik adalah yang paling bermanfaat bagi manusia yang lain.", demikian sabda Nabi Muhammad SAW tentang gelar yang bisa diraih manusia. Gelar terbaik ini berasal dari Allah SWT atas prestasi yang diperbuat manusia. Prestasi ditentukan oleh amaliah yang ditunjukkan manusia selama menjalani tugas kekhalifahannya di muka bumi. Peran yang dilakukannya menjadi ukuran identitas yang diperolehnya, baik di mata masyarakat, maupun dalam pandangan Tuhan, serta baik sekarang maupun khususnya masa medatang.

Tidak mudah meraih penghargaan terbaik. Bangak orang berangangan mendapatkan gelar terhormat dalam hidupnya di dunia maupun di akhirat, tetapi tidak semua manusia bisa mendapatkannya. Ada banyak hambatan yang membuat manusia gagal meraih gelar terhormat itu. "Manusia terbaik" adalah gelar yang diberikan oleh Allah SWT untuk manusia-manusia yang hidupnya tidak membiarkan dalam "krisis" atau kelemahan peran-peran strategis di bidang ekonomi, sosial, budaya, pendidikan, hukum, dan agama. Peran yang dimainkan menentukan lahirnya gelar. Peran baik dapat mengantarkan lahirnya banyak kebajikan di bumi, sementara peran buruk dapat melahirkan kerusakan dan bahkan kehancuran dimana-mana. Peran secara edukatif futuristic akan menentukan kualtas peserta didik dalam mengihadapi keragaman atau kompilasi tantangan yang terhampar di dunia kini dan mendatang (fitiristik),

Peran baik yang dilakukan manusia itu diantaranya adalah peran yang memberikan dan menyuburkan kemanfaatan dimana-mana, terlebihlebih bagi kehidupan edukasi subyek didik. Seseorang atau segolongan orang yang semula hidup serba susah, yang kemudian bisa dibebaskan dan disejahterakan oleh sesamanya, maka si pembebas dan penyejahtera ini berarti telah memperoleh gelar terbaik, karena apa yang dilakukan mempertimbangkan aspek futuristiknya.

\section{KESIMPULAN}

Keberhasilan peserta didik dalam dunia pendidikna, salah satunya dari proses pembelajaramnya yang diikutinya. Proses pembelajaran multikultural yang melibatkan peran pendidik dan peserta didik memang merupakan proses pembelajaran yang melibatkan dua subyek didk strategis. Pendidik sebagai pihak yang melakukan transformasi ilmu pengetahuan tentang nilai-nilai multikultural, sementara peserta didik menjadi pihak yang menerimanya untuk dijadikan sebagai pengetahuan atau pijakan dalam

${ }^{22}$ Ibid. 3. 
membangun sikap dan perilaku di tengah keragaman. Hal ini dapat menjadi modal menghadapi aspek futuristiknya.

Kalau peserta didik bisa menunjukkan ucapan, sikap dan perbuatan yang menyerasikan dengan keragaman atau kebinnekaan kultural, etnis, agama, ekonomi, dan lainnya, maka keberadaannya sebagai subyek didik yang sekaligus hidup di tengah masyarakat dengan kondisi pluralistiknya, akan bisa diphami dan digunakan menjadi modal dalam menata pergaulan atau hubungan lintas kepentingan beragam di tengah masyarakat.

\section{DAFTAR PUSTAKA}

\section{Buku}

Abidin Ibnu Rusn, 1998, Pemikiran Al-Ghazali tentang pendidikan,

Yogyakarta: Pustaka Pelajar Offset.

Ahmad Syafii Maarif, Membumikan Islam, Pustaka Pelajar, Yogyakarta, 1995

Ahmad Tafsir, Filsafat Pendidikan Islam, Remaja Rosdakarya, Bandung, 2006,

Azyumardi Azra, 2011. Culture Pluralism in Indonesia: Local, National, and Global Exchanges, dalam Eva Hoffman" (ed). London

BS. Mardiatmadja, 1986, Tantangan Dunia Pendidikan, Yogyakarta: Kanisius, Yogyakarta.

Chabib Thoha, 1996, Kapita Selekta Pendidikan Islam, Yogyakarta: Pustaka Pelajar.

Endang Turmudi (ed), 2005, Islam dan Radikalisme di Indonesia, Jakarta: LIPI Press.

Mahfud, 2006, Pribadi yang Pintar dan Benar, materi Kultum bagi Kaum terdidik, Surabaya: Prima Mustika.

Muhammad Tholhah Hasan, 2001 Diskursus islam kontemporer, Jakarta: Listafariska Putra.

Jakarta: Galasa Nusantara.

Nurcholish Madjid, 1997, Masyarakat religius, Jakarta: Amanah Putra Nusantara.

Sahal Mahfudh, 1994, Nuansa fiqih sosial, Yogyakarta: LKIS.

Zuhairi, dkk, 2004, Filsafat Pendidikan Islam, Bandung: Bumi Aksara. 


\section{Makalah}

Muhammat Tholchah Hasan, "Pendidikan Islam dalam Menghadapi Perkembangan Global", Materi disampaikan dalam kuliah umum tanggal 16 Pebruari 2008. 